\title{
Review
}

\section{Overview on poly(ADP-ribose) immuno-biomedicine and future prospects}

\author{
By Yoshiyuki KANAI ${ }^{* 1, \dagger}$ \\ (Communicated by Takashi SugimurA, M.J.A.)
}

\begin{abstract}
Poly(ADP-ribose), identified in 1966 independently by three groups Strassbourg, Kyoto and Tokyo, is synthesized by poly(ADP-ribose) polymerases (PARP) from $\mathrm{NAD}^{+}$as a substrate in the presence of $\mathrm{Mg}^{2+}$. The structure was unique in that it has ribose-ribose linkage. In the early-1970s, however, its function in vivo/in vitro was still controversial and the antibody against it was desired to help clear its significance. Thereupon, the author tried to produce antibody against poly(ADP-ribose) in rabbits and succeeded in it for the first time in the world. Eventually, this success has led to the following two groundbreaking papers in Nature: "Naturally-occurring antibody against poly(ADP-ribose) in patients with autoimmune disease SLE", and "Induction of anti-poly(ADP-ribose) antibody by immunization with synthetic double-stranded RNA, $\operatorname{poly}(\mathrm{A}) \cdot \operatorname{poly}(\mathrm{U}) "$.

On the way to the publication of the first paper, a reviewer gave me a friendly comment that there is "heteroclitic" fashion as a mechanism of the production of natural antibody. This comment was really a God-send for me, and became a train of power for publication of another paper, as described above. Accordingly, I thought this, I would say, episode is worth describing herein. Because of its importance in biomedical phenomena, a certain number of articles related to "heteroclitic" have become to be introduced in this review, although they were not always directly related to immuno-biological works on poly(ADP-ribose). Also, I tried to speculate on the future prospects of poly(ADP-ribose), product of PARP, as an immuno-regulatory molecule, including either induced or naturally-occurring antibodies, in view of "heteroclitic".
\end{abstract}

Keywords: poly(ADP-ribose), PARP, anti-poly(ADP-ribose), double-stranded RNA poly $(\mathrm{A}) \cdot \operatorname{poly}(\mathrm{U})$, heteroclitic/heterospecific

\section{Preface}

Since I left from laboratory works on poly(ADPribose), nearly a decade has passed. During the period, however, I continued thinking about the immuno-biological problems of poly(ADP-ribose) with different angle from most of scientists working on poly(ADP-ribose). Recently, as if the situation was saw through, Dr. Takashi Sugimura, one of the trailblazers of poly(ADP-ribose) science solicited me to describe mainly on the immuno-biochemistry and/ or biomedicine of poly(ADP-ribose) in which I have

*1 Choju Medical Institute, Fukushimura Hospital, Noyori, Toyohashi, Aichi, Japan.

$\dagger$ Correspondence should be addressed: Y. Kanai, Choju Medical Institute, Fukushimura Hospital, Noyori, Toyohashi, Aichi 441-8124, Japan (e-mail: kanai@chojuken.net). engaged in between the mid-1970s and the 1980s: e.g., experimental production of antibody against poly(ADP-ribose) in rabbits, and identification of naturally occurring antibody to poly(ADP-ribose) in patients with autoimmune disease systemic lupus erythematosus (SLE) before the verification of in vivo presence of poly(ADP-ribose). Above two achievements were unheard-of and groundbreaking and thus have been listed as milestones in an early monograph of poly(ADP-ribose) science. ${ }^{1)}$ However, the worldwide permeation of their significance was far-difficult, because, retrospectively, the science of poly(ADP-ribose) at that time must have been a handful of biochemistry. Yet our own immunobiochemistry on poly(ADP-ribose) has been proceeded desperately with special focus on medical science. As poly(ADP-ribose) science keeps going up 
to the present time, it will make sense that even groundbreaking achievements at its dawn were put on back burner. Therefore, herein I described our initial painstaking works on immunochemistry of poly(ADP-ribose), and also referred to the immunobiological potentials of poly(ADP-ribose) itself. Also a number of literatures on the neurodegenerative diseases in relation to poly(ADP-ribose) were accompanied by in this review, because I am presently involved in Alzheimer's disease (AD). As was described in detail in this review, the second report, ${ }^{2}$ following the first Nature report on naturallyoccurring antibody in SLE patients, ${ }^{3)}$ was really an outcome resulted from communication in the first paper with the reviewer who referred me to "heteroclitic" fashion as one of the mechanism of "natural antibody production". Unexpected encounter with word "heteroclitic" was episodic, however it was of great value in rethinking about not only monoclonal antibodies that are used all these years without doubt, but also poly(ADP-ribose) itself in terms of its biological potentials.

\section{Springboard to studying poly(ADP-ribose)}

The springboard to study on poly adenosine diphosphate-ribose [poly(ADP-ribose)] was the incidental meeting with Professor Dr. Takashi Sugimura in 1970 at the Institute of Medical Science, University of Tokyo where I was struggling to purify bovine catalase just after getting degree of medical doctor (MD). Professor Sugimura was an expert scientist of catalase in animals bearing tumor in which liver catalase activity was specifically suppressed by so called toxohormon produced in the tumor. ${ }^{4)}$ For the study on catalase, he willingly invited me to the National Cancer Center Institute Tokyo. After 3-4 year-laborious study on rat liver catalase, I have succeeded in the purification of catalase and thus produced antibody to it. It was so efficient and specific for catalase that I could succeed in the chase of in vivo degradation of inactivated catalase in parallel with active catalase. Result elegantly showed that inactivated catalase in vivo by 3-amino1,2,4-triazole (AT) was decayed three times faster than active catalase. These experimental results have been published in Journal of Biological Chemistry in 1974. ${ }^{5)}$ These findings suggested that in vivo AT-modified and inactivated molecules were recognized as foreign bodies (modified autoantigen) and quickly extirpated outside the body under physiological conditions. In fact, it has been shown that immunization of rabbits with AT-modified catalase induced stronger antibody than native catalase (not published). Retrospectively, from this moment, my study should have been destined to work on autoimmunity in the future. It seems to be inevitable consequence that it is now accepted that "autophagy" misconduct, namely, the storage of useless substances is leading to some degenerative diseases such as Alzheimer's disease (AD) and autoimmune diseases. ${ }^{6}$

\section{Production of antibodies to poly(ADP-ribose)}

At that time when I have published the article mentioned above, our laboratory headed by Sugimura was desperately working on poly(ADP-ribose): its finding in vitro and the structure too were reported by Chambon group in France, Hayaishi group in Kyoto and Sugimura group in Tokyo, quite coincidentally but under different situation in between 1966 and 1967. This historic happenings are out of the scope of my review. So that, for the details, refer to the reviews by Sugimura, ${ }^{7)}$ and Hayaishi and Ueda. ${ }^{1)}$ Mentioning briefly the background, however, poly(ADP-ribose) finding by Sugimura group has based upon a report by Chambon et al. ${ }^{8)}$ that $\operatorname{poly}(\mathrm{A})$ polymerase was stimulated 1000 -fold by nicotinamide mononucleotide (NMN). But, it was soon proved by Sugimura group that the product was not poly(A) but poly(ADP-ribose). Meanwhile, Hayaishi group also reached poly(ADP-ribose) finding as an outcome after extensive studies on tryptophan metabolism for a long time. Chambon group too have reported that the enhanced product by NMN found by their own was poly(ADP-ribose).

However, for the time being, poly(ADP-ribose) was still the in vitro product by synthesized by naturally occurring enzyme, poly(ADP-ribose) synth(et)ase (PARP), first purified from calf thymus by Hayaishi group: ${ }^{9), 10)}$ its name was officially recommended by the Nomenclature Committee of the International Union of Biochemistry. ${ }^{10)}$ Poly(ADPribose) was synthesized by PARP from nicotinamide adenine di-nucleotide (NAD) as substrate in the presence of $\mathrm{Mg}^{2+}$ : NAD was synthesized first from NMN and adenosine triphosphate (ATP) by NMN pyrophosphorylase. The NAD is then utilized to form poly(ADP-ribose) by repeated formation of ribose-ribose linkage between ADP-ribose (Fig. 1) up to 100 units by PARP. ${ }^{7}$ ) In depth studies on the structure have revealed that ribose-ribose linkage was further added to the main chain, giving rise to blanch formation. ${ }^{11), 12)}$ The first ADP-ribose unit was supposed to be covalently attached to chromatins. 


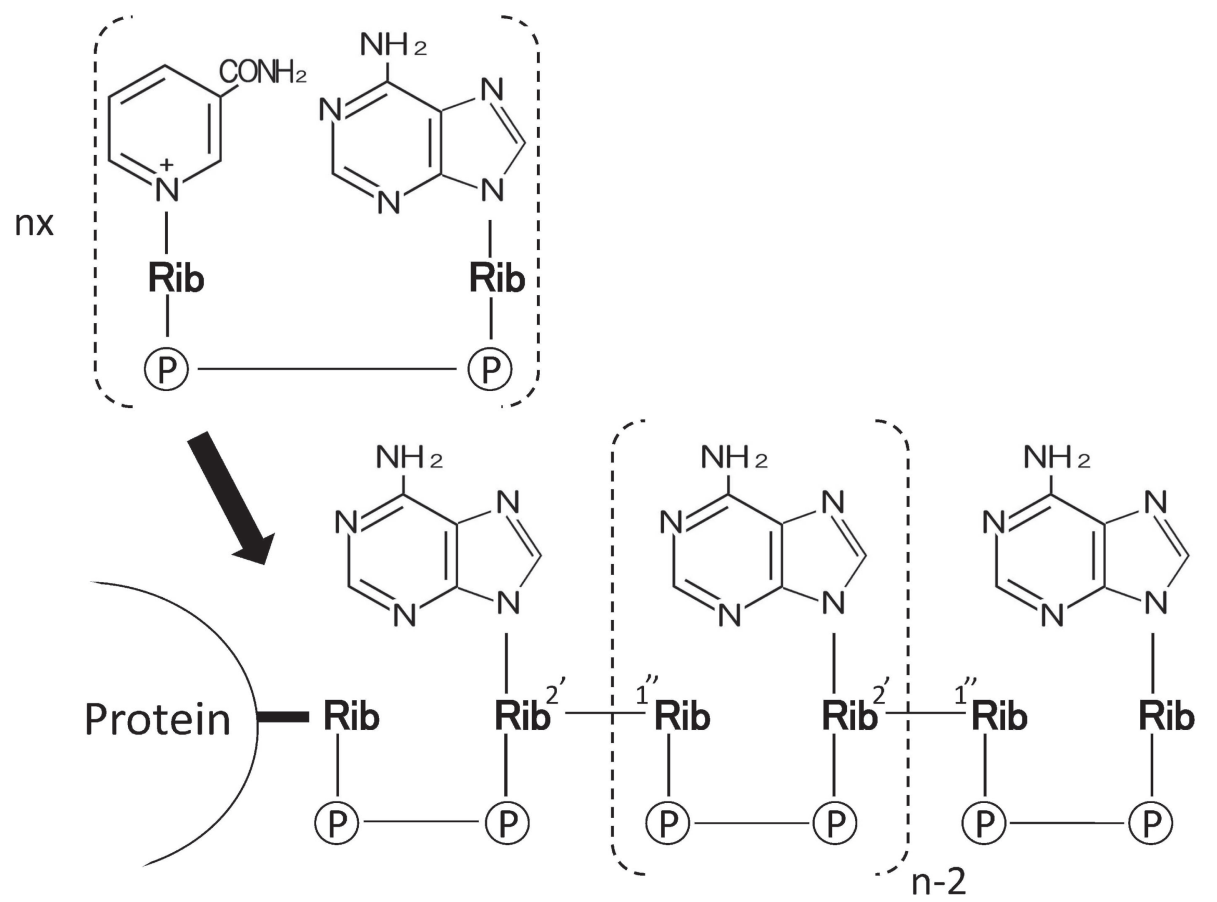

Fig. 1. Structure of Poly(ADP-ribose). Above: NAD ${ }^{+}$, precursor for Poly(ADP-ribose). Bottom: Poly(ADP-ribose) attached to nuclear protein. Illustration of poly(ADP-ribose) structure was depicted according to Refs. 1 and 7 cited in the text.

Soon it has shown that (ADP-ribosyl)ated sites were on histone $\mathrm{H} 1$ of which amino acid residues were both glutamic acid and aspartic acid. ${ }^{13), 14)}$ In order to clarify its in vivo presence and biological roles, we thought that antibody to poly(ADP-ribose) would be the most powerful tool. Based upon our immunochemical experience on catalase, ${ }^{3)}$ we undertook the production of antibody to poly(ADP-ribose) in rabbits according to the method established in case of the production of anti-nucleic acids. ${ }^{15), 16)}$ As expected, antisera raised in rabbits were found contained mono-specific antibody to poly(ADPribose), namely, it did cross-react with neither DNA nor RNA and related nucleic acids so far. This was clearly seen as one band of precipitin on the agar plate by the Ouchterlony method (Fig. 2). This work was the first-ever achievement in poly(ADP-ribose) studies. ${ }^{17)}$ The significance of this achievement indicated that poly(ADP-ribose) is immunogenic, even it was mixed with methylated bovine serum (MBS) that has been established method for the production of antibody to nucleic acids. ${ }^{15)}$ Thus the search for the in vivo presence of poly(ADP-ribose) was within our hands. Instead, we tried to find the natural occurrence of antibodies to poly(ADP-ribose) in autoimmune disease, systemic lupus erythematosus (SLE).

\section{Natural occurrence of antibody to poly(ADP- ribose) in the sera of patients with SLE}

At that time, there were already accumulated evidences and reports that some nucleic acids are immunogenic and SLE patients have anti-DNA antibodies in their serums. ${ }^{18), 19)}$ Under these circumstances, we considered that poly(ADP-ribose) is also molecule(s) of nucleic acids-like nature and have undertook the survey of the presence of antibodies to poly(ADP-ribose) in SLE patients. Initially we thought that the presence of anti-poly(ADP-ribose), if present, will be very minute compared with amounts experimentally produced in rabbits. ${ }^{17)}$ Therefore, essential task was the establishment of a more sensitive radioimmunoassay system than that previously used in rabbit antibodies. Finally, we produced highly radioactive $\left[{ }^{14} \mathrm{C}\right]$ poly(ADP-ribose) probe using highly radioactive $\left[{ }^{14} \mathrm{C}\right] \mathrm{ATP}$ and NMN as substrates by use of calf thymus nuclei as enzymes. The radioimmunoassay we adopted was unique in that complexes formed between antibody and radioactive poly(ADP-ribose) were trapped on a millipore filter after incubation, and its radioactivity was measured by a liquid scintillation counter. A number of serum samples from SLE patients have shown the positive radioactive signals as compared with the 


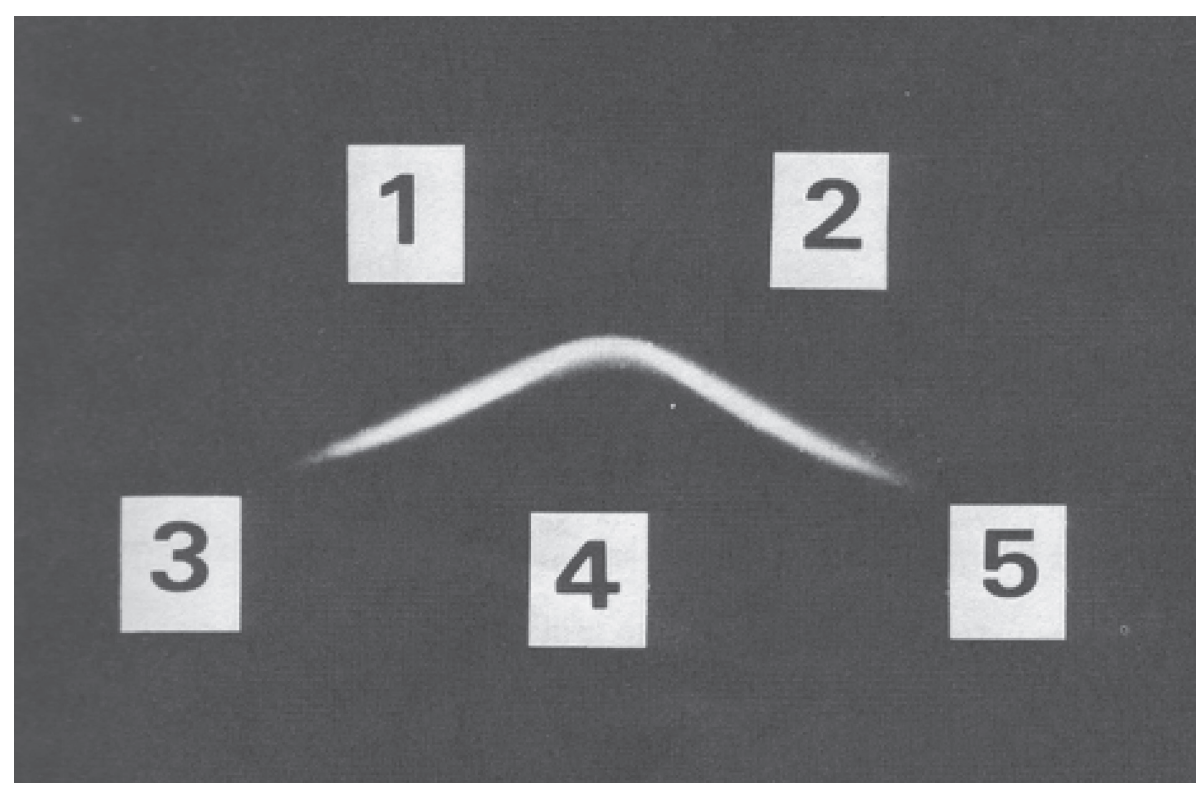

Fig. 2. Immunoprecipitation of poly(ADP-ribose) by Ouchterlony method. Wells 1 and 2 contain anti-poly(ADP-ribose) antibodies. Well 4 contains poly(ADP-ribose), while wells 3 and 5 contain ADP-ribose and poly(A), respectively. This picture is excerpted from original paper, Ref. 17 .

sera of normal individuals. At this point, substantial numbers of unrelated patients with SLE have been tested, but the signals were within normal range. This finding was first presented at the International Symposium on Poly(ADP-ribose) in Tomakomai, Hokkaido, Japan in $1974 .{ }^{20)}$ After the meeting, we submitted the summary of the report to the journal Nature, and then to Proceedings of National Academy of Science, USA (PNAS). The rejection of the paper by the two journals, however, might have been ascribed to the situations that poly(ADP-ribose) was yet a mysterious molecule ${ }^{21)}$ in the field of science and much less popular amongst immunologists as well as the rheumatologists at that time. If I recall, however, it was certain that our claim of the presence of antipoly(ADP-ribose) in SLE patients was too premature: there was neither evidence that the serum binding with poly(ADP-ribose) was real antigenantibody reaction and nor was evidence of in vivo occurrence of antigen, poly(ADP-ribose), even it is synthesized in vitro, as described above. Nevertheless, we desperately continued the experiment to prove the real presence of antibody to poly(ADPribose) in SLE patients.

\section{Final goal of natural occurrence of anti-poly(ADP-ribose) antibody}

Almost three-year-struggle for the proof of the binding of poly(ADP-ribose) with sera of SLE patients has revealed that these bindings were based upon $\mathrm{F}\left(\mathrm{ab}^{\prime}\right)_{2}$ parts of IgG which is binding sites for antigen, while those of $\mathrm{IgG}$ from normal human sera were not. At this stage, we submitted again essentially the same paper as previous one but accompanying the above additional data to Nature office. One month later, I have received a piece of letter from Nature office. The letter said that our paper is acceptable for publication on the condition that some more data with minor revisions are added. For that, several months more have been required, but the paper of the natural occurrence of poly(ADPribose) has been finally accepted for publication. ${ }^{3)}$ Soon after the paper, other groups have shown that our finding was repeatable. ${ }^{22), 23)}$

In order to make the extension of the study on poly(ADP-ribose), we have developed an enzymelinked immunoassay (ELISA) without radioactive probe. ${ }^{24), 25)}$ Using newly developed ELISA, naturally occurring antibody to poly(ADP-ribose) was also found in the sera of autoimmune MRL/lpr mice resembling human SLE, ${ }^{26)}$ and mice undergoing graft-vs-host reactions also produced anti-poly(ADPribose) antibody. ${ }^{27)}$ Moreover, ELISA has shown that anti-poly(ADP-ribose) antibody was found to be dominant in SLE over autoimmune diseases such as scleroderma, mixed connective tissue disease and rheumatoid arthritis. ${ }^{28), 29)}$ 


\section{Induction of anti-poly(ADP-ribose) antibody with double-stranded RNA, $\operatorname{poly}(\mathrm{A}) \cdot \operatorname{poly}(\mathrm{U})$}

One of reviewers on the paper mentioned above, has given me a suggestion that anti-poly(ADPribose) antibody might be induced by the "heteroclitic" reaction due to the in vivo presence of doublestranded RNA. He might have interested in that natural anti-poly(ADP-ribose) antibody was highly reactive with synthetic poly $(\mathrm{A}) \cdot \operatorname{poly}(\mathrm{U})$ used as an inhibitor. This suggestion became a big trigger to yield the second paper ${ }^{2)}$ in the same journal just after the previous one on the natural antibody against poly(ADP-ribose) in SLE patients, as described below.

At that time, term of "heteroclitic" was probably unfamiliar to even Immunologists. "Heteroclitic or heteroclitic antibody" was originally dubbed by Mäkelä and now is defined as an antibody produced by a given antigen (A) with higher affinity for other antigen such as (B) than a given antigen (A). ${ }^{30)}$ At all events, the suggestion above was as if God-send to me, and I tried to immunize rabbits with complexes formed between poly $(\mathrm{A}) \cdot \operatorname{poly}(\mathrm{U})$ and $\mathrm{MBSA}$, as in the case of the production of antibody to poly(ADPribose). ${ }^{17)}$

As was advised, poly $(\mathrm{A}) \cdot \operatorname{poly}(\mathrm{U})$ could really induce not only anti-poly(A)-poly(U) antibody but also anti-poly(ADP-ribose) antibody. At this point, one including myself could imagine that these phenomena were due to structural homology with poly(ADP-ribose) that might be formed by interor intramolecular configuration of poly $(\mathrm{A}) \cdot \operatorname{poly}(\mathrm{U})$. However, surprisingly enough, anti-poly(ADP-ribose) antibody activity was unchanged but rather enhanced after extensive absorption with the immunogen $\operatorname{poly}(\mathrm{A}) \cdot \operatorname{ploy}(\mathrm{U})$ : the specificity to poly $(\mathrm{ADP}$ ribose) remained unchanged at all. At this stage, we have submitted the article describing the finding that "anti-poly(AD-ribose) antibody induced by $\operatorname{poly}(\mathrm{A}) \cdot \operatorname{poly}(\mathrm{U})$ was specific for poly(ADP-ribose)" to Nature. A minor revises were required, but it was smoothly accepted in 1978. ${ }^{2}$ Thus production of anti-poly(ADP-ribose) seemed to be due to "heteroclitic reactions" happened in rabbits during sensitization with $\operatorname{poly}(\mathrm{A}) \cdot \operatorname{poly}(\mathrm{U})$. Taken into account of the structural difference of sugar-phosphate backbone between two antigens, it could be ruled out that structural similarity gave rise to anti-poly(ADPribose). Moreover, failure in the production of antipoly(ADP-ribose) by immunization with poly(I). poly $(C)$ in rabbits supported this ideas. It is of note the statement/definition by Mäkelä that heteroclitic antibody could not be produced by metabolites of immunogens, but it could be by stimulation by chance of pre-existing heterogeneous antibody forming cells during immunization. ${ }^{31)}$ The similar opinion on heteroclitic antibody was made by Walters and Wigzell. ${ }^{32)}$ But it should be reconsidered that this notion was extracted by the experiment using a combination of plaque-forming cells and so called a hapten-carrier as antigens that was commonly used at that time, as will be described later. Whatever difference in the antibody-detecting system used is, it seemed plausible that anti-poly(ADP-ribose) antibody in SLE patients could be produced in part by heteroclitic mode by naturally occurring doublestranded RNA found in HeLa cells or in paramyxo viruses infected in the patients. ${ }^{33), 34)}$

\section{Origin and vicissitude of "heteroclitic"}

When the time has passed more than three decades since "our second paper"2) on "heteroclitic" described above, I wonder that "Was anti-poly(ADPribose) antibody induced by $\operatorname{pol}(\mathrm{A}) \cdot \operatorname{poly}(\mathrm{U})$ really heteroclitic?" So, I retrospectively searched the "ontogeny" of heteroclitic antibody or heteroclitic, and noticed that the term originally "heterclitic" has been widely used with time especially in cancer immunology field, such as heteroclitic epitopes, heteroclitic peptides or heteroclitic immunization. ${ }^{35)-38)}$ So I consulted again a few authentic medical dictionaries on this term and confirmed there that heteroclitic antibody is produced in response to immunization with one antigen but have a higher affinity for a second antigen that was not present during immunization. Interestingly enough, Loor, at almost the same era, has independently reported the production of "heterospecific" antibody that was reactive with quite different antigen from the tabacco mosaic virus that was used as immunogen. ${ }^{39)}$ Loor showed that heterospecific antibody was the result of accidentally used different immunoglobulin $\mathrm{H}$ chain from that destined to given antigens during an early period of immunization. It seems to me that both heteroclitic and heterospecific are not always exclusive. Here I would like to refer to classical Eisen's report where he describes that one antigenic determinant is able to induce the synthesis of heterogeneous population of antibodies with large spectra of binding activities for the antigenic determinants. ${ }^{40)}$ He already suggested at that time that there are many antibody forming $B$ cells with different kinds of antigen receptors. A certain kind of $B$ cells bearing specific antigen 
receptors will ripe under the specific excitation to a matured antibody. In this sense, too much talks about either heteroclitic or heterospecific seems to be of no use. The important thing is how we utilize these phenomena in biomedicine, such as therapeutic antibodies, vaccines against infectious or autoimmune diseases.

For the sake of immune enhancement, interferon induction and adjuvant activity by synthetic double stranded RNA, such as poly $(\mathrm{I}) \cdot \operatorname{poly}(\mathrm{C})$ and $\operatorname{poly}(\mathrm{A})$. poly $(\mathrm{U})$ have been studied extensively during the late-1960s to the early-1970s; both activities were due to antigen specific $\mathrm{T}$ cell activation but not antibody producing B cell. ${ }^{41)-49)}$ In 1979, an extensive review has appeared on the immune modulation by synthetic polynucleotides ${ }^{50)}$ in which much was described about the significant role of $\operatorname{poly}(\mathrm{A}) \cdot \operatorname{poly}(\mathrm{U})$, but the review did not refer to our paper that described on "the induction of antibody to poly(ADP-ribose) by poly (A)·poly (U)" reported in $1978,{ }^{2)}$ one year earlier this review. Given that a hapten-carrier system was at that era the royal road to analyze the immune mechanisms by means of plaque-forming cells in agar-coated petri dishes, as mentioned above, ${ }^{31), 32)}$ it would be plausible that our paper was not cited in the review: even the authors describing on the monoclonal antibody produced by injecting poly $(\mathrm{A})$. poly $(\mathrm{U})$ in mice one decade after the aforementioned paper $^{30}$ did not discuss the relation of poly(ADPribose) with poly $(\mathrm{A}) \cdot \operatorname{poly}(\mathrm{U})$, but just cited it as one of the other related papers on anti-nucleic acid antibodies. ${ }^{51)}$

Poly(ADP-ribose) immunology was really heardof at that time as a report that the natural antibody against nucleic acid-like substance introduced as "a mysterious molecule of Japan ${ }^{21) " ~ w a s ~ f o u n d ~ i n ~ a u t o-~}$ immune disease SLE before verification of the in vivo presence of the antigen. Moreover, induction of antipoly(ADP-ribose) antibody by poly (A) $\cdot$ poly (U) must have been hardly acceptable to either immunologists or rheumatologists: it was really hard timing to make immunology society recognized the complexity of poly(ADP-ribose). In fact, facilities for the poly(ADP-ribose) work at that time were limited even in the biochemistry society. Therefore, instead, it would be likely replaced by synthetic polynucleotides such as poly $(\mathrm{I}) \cdot \operatorname{poly}(\mathrm{C})$ and $\operatorname{poly}(\mathrm{G}) \cdot \operatorname{poly}(\mathrm{C})$ in immunology society. Under such circumstances, poly (ADP-ribose)/poly $(\mathrm{A}) \cdot \operatorname{poly}(\mathrm{U})$ potentials for its induction of heterocliticity/heterospecificity and interferon or of adjuvant activity must have been put on back burner. Of great regret was that unheard-of such phenomena have not been investigated further even by our own hand.

Since our first production of antibody to poly(ADP-ribose) in rabbits, a few laboratories studying poly(ADP-ribose) have shown the ex vivo presence of poly(ADP-ribose) by use of anti-poly(ADP-ribose) antibody obtained by our method. ${ }^{52), 53)}$ For the in vivo demonstration of poly(ADP-ribose) at that time, the most crucial thing was to rule out the possible artifact of the polymer during cell or tissue handling. Because all type of cells except fully matured lymphocytes had contained enough PARP to synthesize poly(ADP-ribose). Moreover, in case of using an immune-fluorescent antibody in which antibody is labeled with fluorescein, purity and antigen specificity were strictly required. Different from today's easy estimation on fluorescent staining, stained tissues all with the labeled antibody could not be considered as the real presence of antigen such as poly(ADP-ribose). Therefore, excess labeled antibody was excluded so as not to increase in the nonspecific binding to the target. In addition to the strict selection of labeled antibody, possible formation of artifact by de novo synthesis by PARP during staining process must be completely blocked under the presence of PARP inhibitor 3-aminobenzamide (3-AB) during staining process. 3-AB have been developed as an analog of nicotinamide to verify the role of poly(ADP-ribose) by Purnel and Whish in $1980 .{ }^{54)}$ Under such a severe condition, I finally succeeded in staining poly(ADP-ribose) in cultured HeLa cell. Staining was especially seen in the M phase of chromosomes together with very fine granular one in nucleoplasmids (Fig. 3). ${ }^{55)}$ Immunofluorescence detected at this moment couldn't show how length of the polymer. Because anti-poly(ADP-ribose) antibody produced in rabbits was against roughly more than 20 ADP-ribose units. Concern at this time was whether the antibody could detect how short of polymer, that is, oligomer of ADP-ribose with several ADP-ribose units. Above questions drove us further to challenge the production of antibody against oligo (ADP-ribosyl)ated histones.

\section{Production of anti-poly(ADP-ribose) by (ADP-ribosyl)ated histone}

In vitro studies at that time have indicated that ADP-ribosylation of chromatin occurs mainly in the histone $\mathrm{H} 1$ and $\mathrm{H} 2 \mathrm{~B}$, and have also suggested nonhistone proteins may undergo ADP-ribosylation. ${ }^{13), 14)}$ We considered oligo(ADP-ribosyl)ated histone with several ADP-ribose units is more stable 


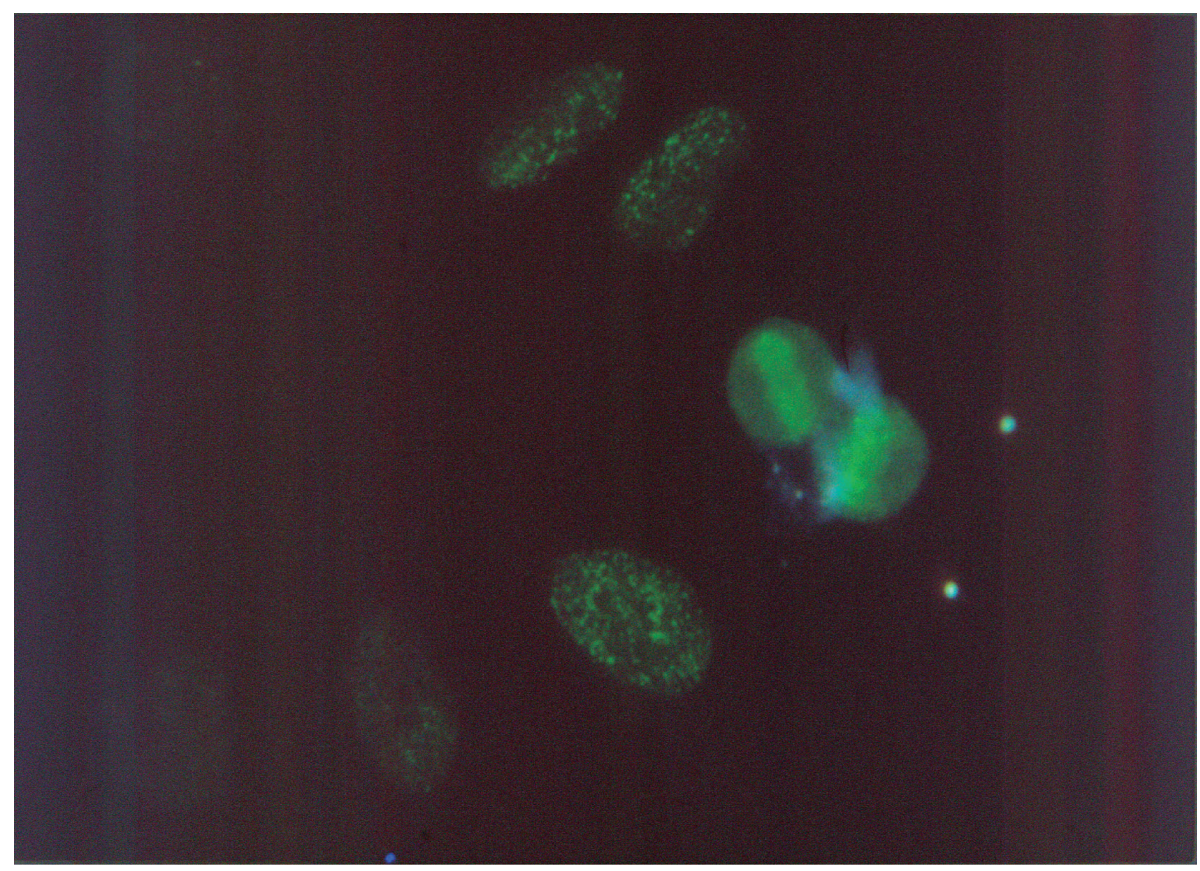

Fig. 3. Immunofluorescent staining of Poly(ADP-ribose) in M phase chromosomes of HeLa cells. For full details of this fluorescence, see original paper cited as Ref. 55 in this text.

in vivo than free poly(ADP-ribose) with more than 10 ADP-ribose units. OligoADP-ribosylated histone was considered as if hapten-carrier system as mentioned above, that is, the carrier protein should be histone, and oligo(ADP-ribose) be equivalent to hapten in this system. Therefore, oligo(ADPribosyl)ated histone was expected to be a good immunogen. Actually, immunization of rabbits with this complex has produced antibodies reactive with poly(ADP-ribose). ${ }^{56)}$ Thus produced antibody was equally inhibited with poly(ADP-ribose) as in the case of antibody produced by poly(ADP-ribose) in rabbits. Interestingly, antibody induced by oligo(ADP-ribosyl)ated histone was scarcely inhibited by oligomer of ADP-ribose, whereas the one induced by poly(ADP-ribose) was not at all, indicating that antibody even induced by oligomer showed higher affinity to longer chain of ADP-ribose, namely, poly(ADP-ribose). ${ }^{57)}$ In this sense, anti-poly(ADPribose) antibody induced by oligomer of ADP-ribose also should be within a criteria of "heteroclitic" because it preferred poly(ADP-ribose) much more than given antigen oligomer of ADP-ribose: refer to legend to Fig. 4.

Above findings showed that natural occurrence of antibody to poly(ADP-ribose) in SLE patients could be actually sensitized with (ADP-ribosyl)ated histone. In fact, the demonstration of in vivo occurrence of a cross linked complexes of poly(ADP-ribose) histone by Wong and Kanai et al. would be of interest in view of this possibility ${ }^{58)}$ whatever the cross link occurs in intra or inter chains. Here, it should be mentioned that H1 dimer was only shown by electrophoretic mobility, and chemical bonding to another H1 isn't being revealed yet. It is interesting that apparently one autoantibody could be induced by a variety of mechanisms: such as by metabolic modification of auto antigens or by auto antigenunrelated viral double helical RNA that could induce heteroclitic or heterospecific antibodies as mentioned above. I think now that these evidences seemed not to be seriously considered yet at the initial era when many monoclonal antibodies have began to be reported from many laboratories. In fact, many monoclonals were heteroclitic and more or less cross reactive or polyreactive with related- or even nonrelated antigens, that is, heterospecific. ${ }^{59)-62)}$ Possible production model of anti-poly(ADP-ribose) antibody by poly or oligo(ADP-rybosil)ated histone is illustrated in Fig. 4: the role of auto-antibody and autoantigen like nucleic acids and poly(ADP-ribose) in systemic autoimmune disease SLE has long been debated. However, since epigenetic modification of the proteins (nucleic acids are probably the case) 

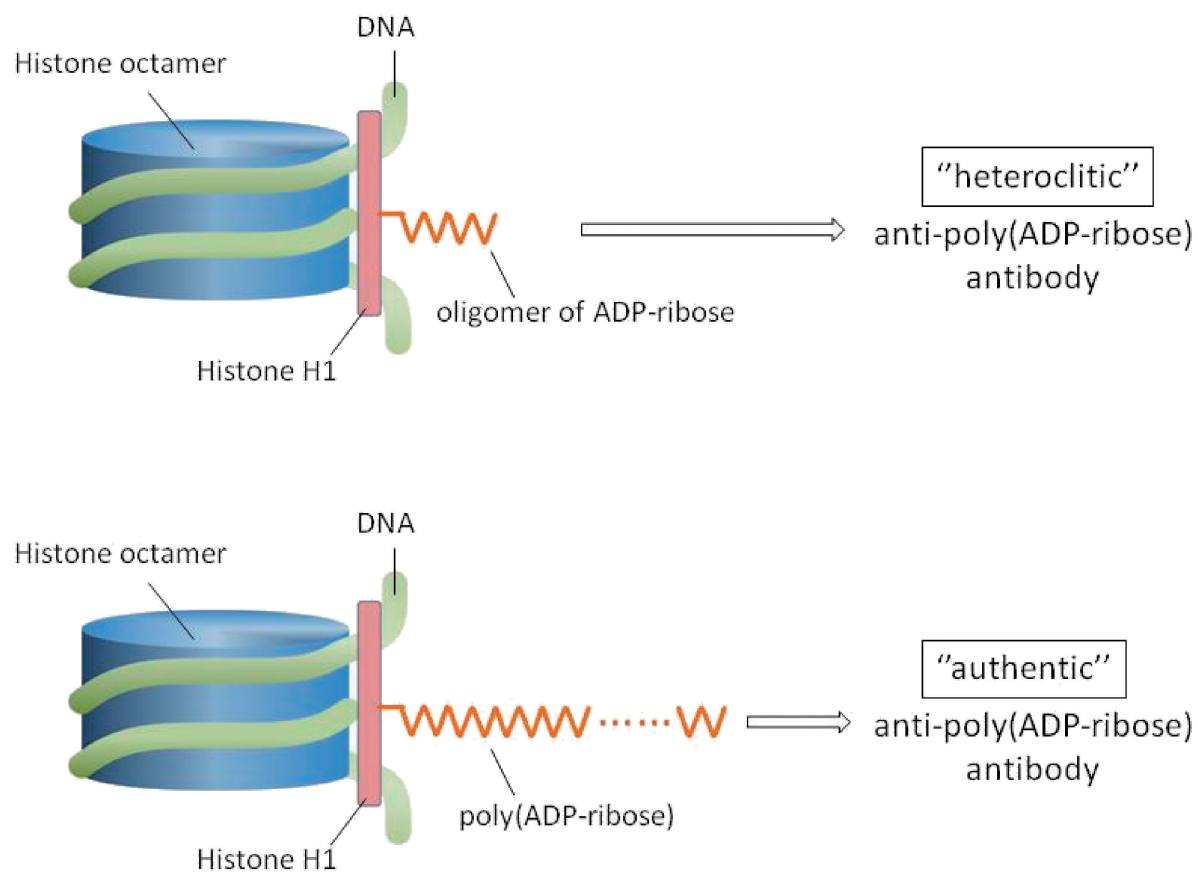

Fig. 4. Mode of production of heteroclitic (top) or of authentic anti-poly(ADP-ribose) antibody (bottom) by oligo(ADP-ribosyl)ated histone (top) or by poly(ADP-ribosyl)ated histone (bottom). Here, histone $\mathrm{H} 1$ is shown as a representative. Antibody induced even by oligoADP-ribosylated histone preferred poly(ADP-ribose) but not oligomer of ADP-ribose (top). Whereas antibody induced or produced by poly(ADP-ribose) preferred the relevant antigen poly(ADP-ribose) but not oligomer of ADP-ribose (bottom). That is why the former is "Heteroclitic". This illustration was constructed according to our original papers referred to as Refs. 56 and 57.

became focused biochemically, immunologists also became aware of the importance of such modified proteins in systemic autoimmune disease as the mechanism of rendering immunogenic in vivo. ${ }^{4)}$ Rendering native substances immunogenic in vivo is said to be the breakage of "immunological tolerance", the details of which have recently been extensively reviewed, where ADP-ribosylation of histone is also described as a frontier in this field. ${ }^{63)}$ It should be noted that ADP-ribosylation to histones could render histones immunogenic (data not shown).

\section{Era of monoclonal antibodies}

Since the establishment for the technique of hybridoma formation by Köhler and Milstein, ${ }^{64)}$ many laboratories have engaged in producing hybridomas from autoimmune disease model animals to evaluate the relation between autoantigens and a single molecule of autoantibody: a certain laboratories intended to produce monoclonal antibodies by immunization of normal animals such as rabbits with their interest molecules to analyze the molecular dynamics biochemically. However, monoclonals obtained in many laboratories were not always mono- specific to a given antigen as mentioned. Our monoclonals from autoimmune MRL/lpr mouse were also the case. ${ }^{65)}$ For us too, hybridomas producing a monoclonal antibody was considered to be the best way to analyze the mechanism of antibody formation to poly(ADP-ribose). Because, in advance, we have confirmed that the sera of autoimmune model MRL/ lpr mice also contained antibodies reactive with poly(ADP-ribose), ${ }^{26}$ ) although they were not the same as those seen in SLE patients. At that time, for scientists who engaged in autoimmune analysis, such findings of polyreactivity of monoclonals were beyond the scope of expectations. Based upon a barrel of reports showing polyreactivity of monoclonal antibodies, many laboratories have engaged in the sequence of antibody-binding $\mathrm{V}$ genes of monoclonal antibodies. These studies showed that polyreactivity is depend on the stage of antibody forming B cell maturation where it is possible that the germ-line could be mutated under various B cell situations: the more antigenic stimulation occurs, the more higher affinity antibody is produced. ${ }^{66)}$ Taking account of the situation or stage of maturation of antibodyproducing $\mathrm{B}$ cells in autoimmune model mice, it was 
quite natural that established hybridomas could produce a variety of monoclonal antibodies. It was found that our polyreactive monoclonal antibody derived from an MRL/lpr mouse had also used a germ-line of $\mathrm{V}$-gene. ${ }^{67)}$ One of exceptional cases will be the first monoclonal antibody H10 to poly(ADPribose) obtained from normal mouse immunization with poly(ADP-ribose), seemed to prefer the repetition of ribose-ribose linkage but not blanched structure. $^{68)}$

\section{Significance in obstetrics of poly(ADP-ribose)/ anti-poly(ADP-ribose) antibody}

During the studies of anti-poly(ADP-ribose) on the gestation in autoimmune MRL/lpr mice which was known to have small litter size of fetus compared with that of normal counterpart, it was found that the number of fetus of the mice and titers of antipoly(ADP-ribose) were anti-parallel, namely, the mice with high titers of anti-poly(ADP-ribose) gave rise to low litter size of fetus. ${ }^{69)}$ Thus we suspected that loss of fetus is due to the over production of poly(ADP-ribose) under the autoimmune disorder like SLE. In human pregnant case too, we have confirmed that SLE patients who had high titer of anti-poly(ADP-ribose) tended to fetal loss just after trimester. ${ }^{70)}$ These data from mice and humans suggested us that anti-poly(ADP-ribose) might involve in fetal loss and that the antibody could be produced by the excess production of poly(ADP-ribose) or by excess ADP-ribosylation of chromatin proteins. In order to prove this hypothesis, we administered PARP inhibitor benadrostin (BD), which has been isolated from the fermentation broth of Streptomyces flavovirens $\mathrm{MH} 499-\mathrm{O}^{\prime} \mathrm{F} 1,{ }^{71)}$ to female MRL/lpr mice. As expected, the number of fetus produced from the mice received $\mathrm{BD}$ was increased comparable to that of counterparts just given solvent alone. ${ }^{72)}$ This result at least indicated that antigen poly(ADP-ribose) and/or anti-poly(ADP-ribose) antibody might be involved in such fetal loss.

At this moment, the possibility that PARP inhibitors had some immune regulatory potentials was completely out of my considerations. While I was searching for the literature on 3-AB, I have happen to find a paper that $3-\mathrm{AB}$, the first PARP inhibitor synthesized in 1980 as mentioned above, could modulate natural killer cells (NK) or lymphokineactivated killer cells (LAK). ${ }^{73), 74)}$ This strongly ignited me to consider yet unknown functions of PARP inhibitors for future clinical applications to such as neurodegenerative disease and cancer, as described below. In this connection, it should be mentioned that our preliminary test using 3-AB ahead of BD showed the recovery of fetal loss as well (not published). However, we had no idea that whether $\mathrm{BD}$, a microbial product could modulate NK and LAK.

\section{Neurodegenerative diseases and poly(ADP-ribose)}

Glutamic acid, a major central excitatory neurotransmitter, contributes to neuronal degeneration during hypoxia and hypoglycemia. ${ }^{75)}$ Brain ischemia induced by stroke causes DNA fragmentation. ${ }^{76)}$ Moreover, increase of $\mathrm{Ca}^{2+}$ influx elicited by glutamate induces neuronal cell death. ${ }^{77)}$ It is known that excess amount of $\mathrm{Ca}^{2+}$ in the cells activates $\mathrm{Ca}^{2+}$ dependent endonucleases that could hydrolyze chromosomal DNA into fragments, leading to the activation of PARP. ${ }^{78)}$ Cell demise is believed to be due to the deficiency for NAD or ATP as a result of usage of these precursors for the formation of poly(ADP-ribose). However, whether or not the presence of poly(ADP-ribose), the product of PARP, on the site was still unclear yet at that time. On this matter, a decade ago, we had shown the presence of poly(ADP-ribose) in cultured HeLa cells by an immunofluorescent technique using our specific rabbit antibody to poly(ADP-ribose). ${ }^{55)}$ Therefore, that technique made us first to demonstrate the presence of poly(ADP-ribose) in the cerebellar granule cells which were cultured in the presence of a certain amount of glutamate to induce neurotoxicity. ${ }^{79), 80)}$

Soon after above paper on the accumulation of poly(ADP-ribose) in the spot of neurotoxicity in the brain, nitric oxide- or N-methyl-D aspartate-mediated neurotoxicity has shown to be blocked by $3-\mathrm{AB}$ and its homologs by other group. ${ }^{81)}$ Since then, a barrage of papers dealing with cell demise by DNA strand break on the anoxia due to stroke not only in the brain but also in the heart has been reported. ${ }^{82)}$ Among these reports, two papers from Love et al. drew my attention. The first was on neuronal accumulation of poly(ADP-ribose) after brain ischemia, ${ }^{83}$ ) and the second was on the increased poly(ADPribosyl)ation of nuclear proteins in Alzheimer's disease $(\mathrm{AD}){ }^{84)}$ My finding around the same era that anti-poly(ADP-ribose) antibody is present in the sera of AD patients, ${ }^{85)}$ was well consistent with those of above two papers. Well, it was surprise to me that the relation between $\mathrm{AD}$ and (ADPribosyl)ation in the brain had become to be red hot 
topic. Relation between PARP and acute neuronal death or inflammation is clearly depicted by Skaper. ${ }^{86)}$ In terms of the etio-pathogenesis of AD, there appears to be some discrepancy between a transient poly- or (ADP-ribosyl)ation on the site of stroke and its long stay there, if assuming that this relates to the onset of $\mathrm{AD}$ for which usually as many as 10-20 years are required: for the access to the mode of deposit of poly(ADP-ribose) in $\mathrm{AD}$ and its fate in the case of stroke, poly(ADP-ribose) degrading enzymes in vivo, such as phosphodiesterases and glycohydolase should be taken account. ${ }^{87), 88)}$

Main concerns on the DNA strand break in association to the stroke were NAD or ATP depletion due to ADP- or poly(ADP-ribosyl)ation for the DNA strand break repair. ${ }^{86)}$ In case of stroke, transient shortage of NAD is very crucial for the maintenance of energy supply to intact cells around the stroke area to survive. So that one thinks that exogenous supply of NAD may play a role. In this sense, delivery of PARP inhibitor alone to the affected site seems to be irrational because it may rather contribute to retardation of DNA excision repair. Rather the side effects of inhibitors should be taking account: simultaneous administration of NAD and inhibitors might be of use.

\section{Chemopotentiation by PARP inhibitors in cancer therapy}

Initial studies of poly(ADP-ribose) some 4 decades ago have already suggested that it involves in carcinogenesis with special reference to DNA excision repair. ${ }^{89), 90)}$ The consequence of blocking of the synthesis of poly(ADP-ribose) in carcinogenesis was one of the great concerns in order to know the function. Therefore, 3-AB was first-ever inhibitor for PARP synthesized as a metabolic competitor for $\mathrm{NAD}^{+}$which was a substrate for PARP synthesis, as described above. ${ }^{54)}$ Triggering of red hot focusing of the inhibitors of PARP will be the appearance of papers from 1994 to 2005 in which ovarian or breast cancers defected in tumor suppressors, BRCA1 (breast cancer 1, early onset) or BRCA2, were especially sensitive to PARP inhibitors. ${ }^{91)-93)}$ Since then, desperate hunting worldwide of excellent PARP inhibitors in the management of BRCAassociated breast and ovarian cancers is under way. ${ }^{94), 95)}$ Of note is that PARP inhibitors developed as above have nicotinamide (NA) "pharmacophore". It must be considered here that PARP inhibitors containing NA pharmacopore may have immune regulatory function, as seen in $3-\mathrm{AB} .^{73), 74)}$
It seems to me that there exists disharmony between societies of cancer academy and of neurodegenerative disease academy in terms of usage of PARP inhibitors as their treatment. It is of no use being in fierce contention as to the application of PARP inhibitors to these two diseases of apparent different criterion, although, patho-physiologically their fundamentals are partially the same. Here, it should be kept in mind that main concern of poly(ADP-ribose) study has been primarily toward cancer. Thus, as a scientist who, at present, more or less, involves in two fields, my simple question is whey neuroscientists as successors do not have contact with learned experts in cancer/poly(ADP-ribose) research. In relation to this matter, I happened to find a mini-review on PARP-1 inhibition, in which trail of poly(ADP-ribose) studies since 1963 and recent pharmaceutical application of PARP-1 are neutrally described. ${ }^{96)}$ This review will be of especially use for the reader in the PARP field as well as so called "non PARPist" to understand the PARP world.

\section{Conclusions}

This overview was written focusing on the immuno-biomedicine of poly(ADP-ribose) with special reference to that done during the period from the mid-1970s to the 1980s. However, looking back over the history of poly(ADP-ribose), I really felt that nothing could be talked about poly(ADP-ribose) science without its esoteric roles in DNA excision repair explored in the early-1980s as described in this review. All these years, however, a certain focus is directed to PARP inhibitors by which the loss of functions such as motor neuron paralysis occurs just after stroke could be ameliorated. Their applications to chronic inflammation such as rheumatic diseases and ulcerative colitis are being considered as well. ${ }^{82)}$ Moreover, Altzheimer's disease (AD) also will be the target for PARP inhibitors in terms of neuronal cell death, as described. On the other hand, it is better left unsaid that many pharmaceutical companies are in fierce competition in the synthesis or hunting of PARP inhibitors as a chemopotentiator in cancer. In contrast, however, as to the role of poly(ADPribose), much remains to be studied yet. As referred to in this review, poly(ADP-ribose) alone seems to have potentials as an immuno-modulator. Moreover, I expect heteroclitic/heterospecific actions by poly(ADP-ribose) sensitization in vivo, as seen, for example, in a report by Sibley et al. ${ }^{97)}$ In this context, the possible presence with as yet undetermined naturally occurring double stranded RNAs 
may augment its function in which innate immunity and Toll-like receptors (TLRs) are involved. ${ }^{98)-102)}$ In this sense, it might be of use to apply the classic method to produce a large amounts of poly(ADPribose) as far as calf thymuses a source of PARP are available. $^{103)}$

Presently, poly(ADP-ribose) polymerase (PARP), initially called poly(ADP-ribose) synthetase $^{9), 10)}$ constitutes a large family of 18 proteins, encoded by different genes. ${ }^{104)}$ PARP-1 is the founding member and is activated by DNA strand break. ${ }^{89), 90)}$ Therefore, I would like to remind readers that PARP used in this review means PARP-1. After the completion of this overview, I happened to find the paper by Kurukenberg et al. describing on the relation between innate immunity and extracellular poly(ADP-ribose $)^{105)}$ which seems to be first-ever in terms of focusing on poly(ADP-ribose) alone, that is, extracellular poly(ADP-ribose). This was really like a blot from the blue.

\section{Acknowledgements}

This work was supported in part by Grantsin-Aid for Scientific research from the Ministry of Education, Science, and Culture, and the Ministry of Health and Welfare of Japan. Also I would like to express my sincere thank to Ms. Keiko Kinoshita, the Institute of Medical Science, University of Tokyo for preparing references of volumes. And for preparing figure illustrations, I would like to thank Mr. Takeshi Kanesaka, Fukushimura Hospital.

\section{References}

1) Hayaishi, O. and Ueda, K. (1982) Poly- and mono(ADP-ribosyl)ation reactions: their significance in molecular biology. In ADP-ribosylation Reactions (eds. Hayaishi, O. and Uerda, K.). Academic, New York, pp. 3-16.

2) Kanai, Y., Sugimura, T. and Matsushima, T. (1978) Induction of specific antibody to poly(ADPribose) in rabbits by double-stranded RNA, poly(A)·poly(U). Nature 274, 809-812.

3) Kanai, Y., Kawaminami, Y., Miwa, M., Matsushima, T. and Sugimura, T. (1977) Naturally-occurring antibodies to poly(ADP-ribose) in patients with systemic lupus erythematosus. Nature 265, 175-177.

4) Hozumi, M., Matsuoka, K. and Sugimura, T. (1967) Immunochemical studies on the liver catalase depression by toxohormone. GANN (Japanese Journal of Cancer Research) 58, 555-563.

5) Kanai, Y., Sugimura, T., Matsushima, T. and Kawamura, Y. (1974) Studies on in vivo degradation of hepatic catalase with or without modification by 3-amino-1,2,4-triazole. J. Biol.
Chem. 249, 6505-6511.

6) Pierdominici, M., Vomero, M., Barbati, C., Colasaniti, T., Maselli, A., Vacira, D., Giovannetti, A., Malorni, W. and Ortana, E. (2012) Role of autophagy in immunity and autoimmunity, with a special focus on systemic lupus erythematosus. FASEB J. 26, 1400-1412.

7) Sugimura, T. (1973) Poly(adenosine diphosphate ribose). Prog. Nucleic Acid Res. Mol. Biol. 13, 127-151.

8) Chambon, P., Will, J.D. and Mandel, P. (1963) Nicotinamide mononucleotide activation of new DNA-dependent polyadenylic acid synthesizing nuclear enzyme. Biochem. Biophys. Res. Commun. 11, 39-43.

9) Ito, S., Shizuta, Y. and Hayaishi, O. (1979) Purification and characterization of poly(ADPribose) synthetase from calf thymus. J. Biol. Chem. 254, 3647-3651.

10) Ueda, K., Kawaichi, M. and Hayaishi, O. (1982) Poly(ADP-ribose) synthetase. In ADP-ribosylation Reactions (eds. Hayaishi, O. and Uerda, K.). Academic, New York, pp. 117-155.

11) Miwa, M., Saikawa, N., Yamaizumi, Z., Nishimura, N. and Sugimura, T. (1979) Structure of poly(adenosine diphosphate ribose): Identification of $2^{\prime}$-[1"'-ribosyl-2"-(or 3"'-)(1"'-ribosyl)adenosine$5^{\prime}, 5^{\prime \prime}, 5^{\prime \prime \prime}$-tris(phosphate) as a branch linkage. Proc. Natl. Acad. Sci. U.S.A. 76, 595-599.

12) Sugimura, T. and Miwa, M. (1982) Structure and properties of poly(ADP-ribose). In ADP-ribosylation Reactions (eds. Hayaishi, O. and Uerda, K.). Academic, New York, pp. 43-63.

13) Ogata, N., Ueda, K., Kagamiyama, H. and Hayaishi, O. (1980) Identification of gulutamic acid residues 2,14, and the $\mathrm{COOH}$-terminal lysine residue as a modification sites. J. Biol. Chem. 255, 7616-7620.

14) Adamietz, P. (1982) Acceptor proteins of poly(ADP-ribose). In ADP-ribosylation Reactions (eds. Hayaishi, O. and Uerda, K.). Academic, New York, pp. 43-63.

15) Sueoka, N. and Chen, T.-Y. (1962) Fractionation of nucleic acids with methylated albumin column. J. Mol. Biol. 4, 161-172.

16) Placia, O.J., Braun, W. and Paalczuk, N.C. (1964) Production of antibodies to denatured deoxyribonucleic acid (DNA). Proc. Natl. Acad. Sci. U.S.A. 52, 279-285.

17) Kanai, Y., Miwa, M., Matsushima, T. and Sugimura, T. (1974) Studies on poly(adenosine diphosphate ribose) antibody. Biochem. Biophys. Res. Commun. 59, 300-306.

18) Tan, E.M., Schur, P.H., Carr, R.I. and Kunkel, H.G. (1966) Deoxy ribonucleic acid (DNA) and antibodies to DNA in the sera of patients with systemic lupus erythematosus. J. Clin. Invest. 45, 1732-1740.

19) Koffler, D., Carr, R., Agnello, V., Thoburn, R. and Kunkel, H.G. (1971) Antibodies to polynucleotides in human sera: antigenic specificity and relation to disease. J. Exp. Med. 134, 294-312. 
20) Kanai, Y., Miwa, M., Matsushima, T. and Sugimura, T. (1975) Proceedings: Anti-poly(ADP-ribose) antibody and its specificity. J. Biochem. 77, 5-6.

21) Shall, S. (1974) Mystery molecule in Japan. Nature $\mathbf{2 5 1}, 466$.

22) Okolie, E.E. and Shall, S. (1979) The significance of antibodies to poly(adenosine diphosphate-ribose) in systemic lupus erythematosus. Clin. Exp. Immunol. 36, 151-164.

23) Le Page, S.H., Dudency, C., Shall, S., Shoenfeld, Y. and Isenberg, D.A. (1980) Disease specificity of antibody to poly(ADP-ribose): the relationships to anti-DNA antibodies and to disease activity in lupus. Autoimmunity 5, 169-177.

24) Kanai, Y., Tauchi, M., Aotsuka, S. and Yokohari, R. (1982) A simple and rapid microenzyme-linked immunosorbent assay for antibodies to poly(ADPribose) in systemic lupus erythematosus. J. Immunol. Methods 53, 355-365.

25) Prasad, S., Thraves, P., Kanai, Y., Sumalson, M. and Dritschilo, A. (1989) A dot-blot method for screening polyclonal and monoclonal antisera to poly(ADP-ribose). J. Immunol. Methods 116, 7985.

26) Kanai, Y. and Fujiwara, M. (1985) Natural occurring antibodies to poly(ADP-ribose) in autoimmune MRL/Mp-lpr/lpr mice. Clin. Exp. Immunol. 59, 132-138.

27) Kimura, M., Ida, S., Shimada, K. and Kanai, Y. (1987) Specificity of anti-nuclear antibodies induced in F1 mice undergoing the graft-vs-host reaction: isotypes and cross-reactivities. Clin. Exp. Immunol. 69, 385-393.

28) Kanai, Y., Moroi, Y., Yokohari, R. and Goto, S. (1983) Profiles of antibodies to poly(ADP-ribose), left-handed Z-DNA and other nuclear constituents in systemic lupus erythematosus and progressive systemic sclerosis. Princess Takamatsu Symp. 13, 93-100.

29) Tauchi, M., Kanai, Y., Hashimoto, H. and Hirose, S. (1986) Specificity of naturally occurring antibodies to poly(ADP-ribose) in patients with systemic lupus erythematosus: determination by an enzyme linked immunosorbent assay. Immunol. Lett. 12, 251-256.

30) Mäkelä, O. (1965) Single lymph node cells producing heteroclitic bacteriophage antibody. J. Immunol. 95, 378-386.

31) Mäkelä, O. (1967) Cellular heterogeneity in the production of anti-hapten antibody. J. Exp. Med. 126, $159-170$

32) Walter, C.S. and Wigzell, H. (1972) Heteroclitic cells in anti-hapten systems: some studies at the cellular and serum level. Cell. Immunol. 5, 570578 .

33) Györkey, F., Sinckovics, J.G., Min, K.M. and Phyllis Györkey, P. (1972) A morphorogic study on the occurrence and distribution of structures resembling viral nucleocapsids in collagen diseases. Am. J. Med. 53, 148-158.

34) Feroroff, N., Wellauer, P.K. and Wall, R. (1977)
Intermolecular duplexes in heterogeneous nuclear RNA from HeLa cells. Cell 10, 597-610.

35) Dyall, R., Bowne, W.B., Weber, L.W., LeMaoult, J., Szabo, P., Moroi, Y., Piskun, G., Lewis, J., Houghton, A.N. and Nikolic-Zugie, J. (1998) Heteroclitic immunization induces tumor immunity. J. Exp. Med. 188, 1553-1561.

36) Gold, J.S., Ferrone, C.R., Guevara-Patino, J.A., Haukins, W.G., Dyall, R., Engelhorn, M.E., Wolchok, J., Lewis, J.J. and Houghton, A.N. (2003) A single heteroclitic epitope determines cancer immunity after xenogeneic DNA immunization against a tumor differentiation antigen. J. Immunol. 170, 5188-5194.

37) Cole, D.K., Edwards, E.S.-J., Wynn, K.K., Clement, M., Miles, J.J., Ladell, K., Ekeruche, J., Gostic, E., Adame, K., Skowera, A., Peakman, M., Wooldrige, L., Price, D.A. and Sewell, A.K. (2010) Modification of MHC anchor residues generates heteroclitic peptides that alter TCR binding and T-cell recognition. J. Immunol. 185, 2600-2610.

38) Zirlik, K.M., Zahrieh, D., Neuberg, D. and Gribben, J.G. (2014) Cytotoxic T cells generated against heteroclitic peptides kill primary tumor cells independent of binding affinity of native tumor antigen peptide. Blood 108, 3865-3870.

39) Loor, F. (1971) On the existence of heterospecific antibodies in sera from rabbits immunized against Tabaco mosaic virus determinants. Immunology 21, 557-564.

40) Eisen, H.N. (1966) The immune response to a simple antigenic determinant. Harvey Lect. 60, 1-34.

41) Field, A.G., Tytell, A.A., Lampson, G.P. and Hilleman, M.R. (1967) Inducers of interferon and host resistance. II. Multistranded synthetic polynucleotide complexes. Proc. Natl. Acad. Sci. U.S.A. 58, 1004-1010.

42) Brown, W. and Nakano, N. (1967) Antibody formation: stimulation by polyadenylic and polycytidylic acids. Science 157, 819-821.

43) Dianzani, F., Cantagalli, P., Gagnoni, S. and Rita, G. (1968) Effect of DEAE-dextran on production of interferon induced by synthetic double stranded RNA in L cell culture. Proc. Soc. Exp. Biol. Med. 128, 708-710.

44) Woodhour, A.F., Friedman, A.A., Tytell, A.A. and Hilleman, M.R. (1969) Hyperpotentiation by synthetic double-stranded RNA of antibody responses to influenza virus vaccine in adjuvant 65 (33983). Proc. Soc. Exp. Biol. Med. 131, 809-817.

45) Schmidtke, J.R. and Johnson, A.G. (1971) Regulation of the immune system by synthetic polynucleotides. I. Characteristics of adjuvant action on antibody synthesis. J. Immunol. 106, 11911200.

46) Cone, R.E. and Marcharionis, J.J. (1972) Adjuvant action of poly $(\mathrm{A}: \mathrm{U})$ on T-cells during the primary immune responses in vivo. Aust. J. Exp. Biol. Med. Sci. 50, 69-77.

47) Hamaoka, T. and Katz, M.D. (1973) Mechanism of adjuvant activity of polyA:polyU on antibody 
responses to hapten-carrier conjugates. Cell. Immunol. 7, 246-260.

48) Straub, S.X., Garry, R.F. and Magee, W.E. (1974) Interferon induction by poly(I) $\operatorname{poly}(\mathrm{C})$ enclosed in phospholipid particles. Infect. Immun. 10, 783792.

49) Cunnington, P.G. and Naysmith, J.D. (1975) Naturally occurring double-stranded RNA and immune responses. I. Effects on plaque-forming cells and antibody formation. Immunology 28, $451-468$

50) Jonson, A.G. (1979) Modulation of the immune system by synthetic polynucleotides. Springer Semin. Immunopathol. 2, 149-168.

51) Delage, G., Nahon, E., Huynh, T., Jeusset, J. and Lacour, F. (1984) A monoclonal antibody to the double-stranded polyribonucleotide complex poly(A)·ploy(U). Mol. Immunol. 21, 939-944.

52) Ikai, K., Ueda, K. and Hayaishi, O. (1980) Immunohistochemical demonstration of poly(adenosine diphosphate-ribose) in nuclei of various rat tissues. Histochem. Cytochem. 28, 670-676.

53) Kidwell, W.R. and Mage, M.G. (1976) Changes in poly(adenosine diphosphate-ribose) and poly(adenosine diphosphate-ribose) polymerase in synchronous HeLa cells. Biochemistry 15, 1213-1217.

54) Purnell, M.R. and Whish, W.J.T. (1980) Novel inhibitors of poly(ADP-ribose) synthetase. Biochem. J. 185, 775-777.

55) Kanai, Y., Tanuma, S. and Sugimura, T. (1981) Immunofluorescent staining of poly(ADP-ribose) in situ in HeLa cell chromosomes in the M phase. Proc. Natl. Acad. Sci. U.S.A. 78, 2801-2804.

56) Kanai, Y. and Sugimura, T. (1981) Comparative studies on antibodies to poly(ADP-ribose) in rabbits and patients with systemic lupus erythematosus. Immunology 43, 101-110.

57) Kanai, Y. and Sugimura, T. (1982) Systemic lupus erythematosus. In ADP-ribosylation Reactions (eds. Hayaishi, O. and Ueda, K.). Academic, New York, pp. 533-545.

58) Wong, M., Kanai, Y., Miwa, M., Bustin, M. and Smulson, M. (1983) Immunological evidence for in vivo occurrence of a crosslinked complex of poly(ADP-ribose) histone H1. Proc. Natl. Acad. Sci. U.S.A. 80, 205-209.

59) Teitelubaum, D., Aharoni, R., Sela, M. and Arnon, R. (1991) Cross-reactions and specificities of monoclonal antibodies against myelin basic protein and against the synthetic copolymer 1 . Proc. Natl. Acad. Sci. U.S.A. 88, 9528-9532.

60) Liu, J., Minnerath, J.M., Nelson, R.D., Mueller, C.M. and Jemmerson, R. (2000) Kinetic and genetic bases for the heteroclitic recognition of mouse cytochrome c by anti-pigeon cytochrome c monoclonal antibody. Mol. Immunol. 37, 847859.

61) Retegui, L.A. and Paladini, A.C. (1986) Heteroclitic behavior of some monoclonal antibodies against bovine growth hormone. Mol. Immunol. 23, 119123.

62) Notkins, A.L. (2004) Polyreactivity of antibody molecules. Trends Immunol. 25, 174-179.

63) Pieterse, E. and van der Vlag, J. (2014) Breaking immunological tolerance in systemic lupus erythematosus. Front Immunol. 5 (Article 164), 1-8.

64) Köhler, G. and Milstein, C. (1975) Continuous cultures of fused cells secreting antibody of predefined specificity. Nature 256, 495-497.

65) Kanai, Y., Akatsuka, T., Kubota, T., Goto, S. and Stollar, B.D. (1985) MRL/Mp-lpr/lpr mouse monoclonal antibodies that recognize determinants shared by poly(ADP-ribose), single stranded DNA and left handed Z-DNA. Clin. Exp. Immunol. 59, 139-145.

66) Baccala, R., Quang, T.V., Gilbert, M., Ternynck, T. and Abramas, S. (1989) Two murine natural polyreactive autoantibodies are encoded by nonmutated germ-line gene. Proc. Natl. Acad. U.S.A. 86, 4624-4628.

67) Yaoita, Y., Takahashi, M., Azuma, C., Kanai, Y. and Honjo, T. (1988) Biased expression of variable region gene families of immunoglobulin heavy chain in autoimmune-prone mice. J. Biochem. 104, 337-343.

68) Kawamitsu, H., Hoshino, H., Okada, H., Miwa, M. and Sugimura, T. (1994) Monoclonal antibodies to poly(adenosine diphosphate ribose) recognize different structures. Biochemistry 23, 3771-3777.

69) Isonishi, S. and Kanai, Y. (1988) Antibody to poly(ADP-ribose) as a predictor of obstetric complications in autoimmune MRL/Mp-lpr/lpr mice: basis for its application to pregnant patients with systemic lupus erythematosus. Immunol. Lett. 18, 61-66.

70) Kanai, Y., Isonishi, S. and Terashima, Y. (1989) Antibody to poly(ADP-ribose) is an indicator of obstetric complications in pregnant patients with systemic lupus erythematosus. Immunol. Lett. 21, $217-222$.

71) Aoyagi, T., Yoshida, S., Harada, S., Okuyama, A., Nakayama, C., Yoshida, T. and Umezawa, H. (1988) Benadrostin, new inhibitor of poly(ADPribose) synthetase produced by actinomycetes. I. Taxonomy, production, isolation, physic-chemical properties and biological activities. J. Antibiotics 41, 1009-1014.

72) Yamauchi, S. and Kanai, Y. (1991) Preferential suppression of antibody to poly(ADP-ribose) in lupus-prone MRL/Mp-lpr/lpr mice by benadrostin. - Basis for its application to pregnant patients with systemic lupus erythematosus for the prevention of fetal loss. Jikeikai Med. J. 38, 387-393.

73) Monti, D., Cossarizza, A., Salvioli, S., Franceschi, C., Rainaldi, G., Straface, E., Rivabene, R. and Malorni, W. (1994) Cell death protection by 3aminobenzamide and other poly(ADP-ribose) polymerase inhibitors: Different effects on human natural killer and lymphokine-activated killer cell activities. Biochem. Biophys. Res. Commun. 199, 525-530.

74) Malorni, W., Rainaldi, G., Straface, E., Rivabene, R., Cossarizza, A., Salvioli, S., Monti, D. and 
Franceschi, C. (1994) Cell Death protection by 3-aminobenzamide: Impairment of cytoskeleton in Human NK cell-mediated killing. Biochem. Biophys. Res. Commun. 199, 1250-1255.

75) Rothman, S.M. (1984) Synaptic release of excitatory amino acid neurotransmitter mediates anoxic neuronal death. J. Neurosci. 4, 1884-1891.

76) Choi, D.W. (1988) Glutamate neurotoxicity and diseases of the nervous system. Neuron 1, 623634.

77) Manev, H., Fararon, M., Guidotti, A. and Costa, E. (1989) Delayed increase of $\mathrm{Ca}^{2+}$ influx elicited by glutamate role in neuronal death. Mol. Pharmacol. 36, 106-112.

78) Choen, J. and Duke, J. (1984) Glucocorticoid activation of a calcium dependent endonuclease in thymocyte nuclei leads to cell death. J. Immunol. 132, 38-42.

79) Coci, C., Suzuki, H., Milani, D., Facci, L., Menegazzi, G., Vantini, Y., Kanai, Y. and Skaper, S.D. (1994) Poly(ADP-ribose) polymerase: Early involvement in glutamate-induced neurotoxicity in cultured cerebellar cells. J. Neurosci. Res. 39, $38-46$.

80) Coci, C., Suzuki, H., Skaper, S.D., Mlani, D., Facci, L., Menegazzi, M., Vantini, G., Kanai, Y., Degryse, A., Corpaert, F., Koek, W. and Marien, M.R. (1997) Poly(ADP-ribose) polymerase (PARP) revisited. A new role for an old enzyme: PARP involvement in neurodegeneration and PARP inhibitors as possible neuroprotective agents. Ann. N.Y. Acad. Sci. 825, 366-379.

81) Zhang, J., Dawson, V.L., Dawson, T.M. and Synder, S.H. (1994) Nitric oxide activation of poly(ADPribose) synthetase in neurotoxicity. Science $\mathbf{2 6 3}$, 687-689.

82) Pacher, P. and Szabo, C. (2008) Biological perspectives. Role of the peroxynitrite-poly(ADP-ribose) polymerase pathway in human disease. Am. J. Pathol. 173, 2-13.

83) Love, S., Barber, R. and Wilcock, G.K. (1999) Neuronal accumulation of poly(ADP-ribose) after brain ischemia. Neuropathol. Appl. Neurobiol. 25, 98-103.

84) Love, S., Barber, R. and Wilcock, G.K. (1999) Increased poly(ADP-ribosyl)ation of nuclear proteins in Alzheimer's disease. Brain 122, 247-253.

85) Kanai, Y., Akatsu, H., Iizuka, H. and Morimoto, C. (2007) Could serum antibody to poly(ADPribose) and/or histone $\mathrm{H} 1$ be marker for senile dementia of Alzheimer type. Ann. N.Y. Acad. Sci. 1109, 338-344.

86) Skaper, S.D. (2003) Poly(ADP-ribose) polymerase-1 in acute neuronal death and inflammation. Ann. N.Y. Acad. Sci. 993, 217-228.

87) Miwa, M. and Sugimura, T. (1971) Splitting of the ribose-ribose linkage of poly(ADP-ribose) by a calf thymus extract. J. Biol. Chem. 246, 6362-6364.

88) Miwa, M. and Sugimura, T. (1982) Phosphodiesterases and poly(ADP-ribose) glycohydrolase. In ADP-ribosylation reactions (eds. Hayaishi, O. and Uerda, K.). Academic, New York, 263-277.
89) Durkacz, B., Omidiji, O., Gray, D.A. and Shall, S. (1980) (ADP-ribose)n participates in DNA excision repair. Nature 283, 593-596.

90) Shall, S. (1982) ADP-ribose in DNA repair. In ADPribosylation Reactions (eds. Hayaishi, O. and Uerda, K.). Academic, New York, pp. 477-520.

91) Miki, Y., Swensen, J., Shattuck-Eidens, D., Futreal, P.A., Harshhman, K. and Tavitigian, S. (1994) A strong candidate for the breast and ovarian cancer susceptibility gene BRCA1. Science 266, 66-71.

92) Wooster, R., Bignell, G., Lancaster, J., Swift, S., Seal, S. and Mangion, J. (1995) Identification of the breast cancer susceptibility gene BRCA2. Nature 378, 789-792.

93) Bryant, H.E., Schulz, N., Thomas, H.D., Parker, K.M., Flower, D., Lopez, E., Kyle, S., Menth, M., Curtin, N.J. and Helleday, T. (2005) Specific killing of BRCA2-deficient tumors with inhibitors of poly(ADP-ribose) polymerase. Nature 434, 913-917.

94) Rodon, J., Iniesta, M.D. and Papadopoulos, K. (2009) Development of PARP inhibitors in oncology. Expert Opin. Investig. Drugs 18, 31-43.

95) Javle, M. and Curtin, N.J. (2011) The role of PARP in DNA repair and its therapeutic exploitation. Br. J. Cancer 105, 1114-1122.

96) Graziani, G., Battaini, F. and Zang, J. (2005) PARP-1 inhibition to treat cancer, ischemia, inflammation. Pharmacol. Res. 52, 1-4.

97) Sibley, J.T., Braun, R.P. and Lee, J.S. (1986) The production of antibodies to DNA in normal mice following immunization with poly(ADP-ribose). Clin. Exp. Immunol. 64, 563-569.

98) Matsumoto, M., Kikkawa, S., Kohase, M., Miyake, K. and Seya, T. (2002) Establisehment of a monoclonal antibody against human Toll-like receptor 3 that blocks double-stranded RNAmediated signaling. Biochem. Biophys. Res. Commun. 293, 1364-1369.

99) Ishii, J.K. and Akira, S. (2005) Mini Rev. Innate immune recognition of nucleic acids: Beyond Tolllike receptors. Int. J. Cancer 117, 517-523.

100) Sugiyama, T., Hoshino, K., Saito, M., Yano, T., Sasaki, I., Yamazaki, C., Akira, S. and Kaisho, T. (2007) Immunoadjuvant effects of polyadenylic: polyuridylic acids through TLR3 and TLR7. Int. Immunol. 20, 1-9.

101) Caskey, M., Lefebvre, F., Filali-Mouhim, A., Cameron, M.J., Goulet, J.-P., Haddad, E.K., Breton, G., Trumpfheller, C., Pollak, S., Shimeliovich, I., Duque-Alarcon, A., Pan, L., Nelkenbaum, A., Salazar, A.M., Schlesinger, S.J., Steinman, R.M. and Sékaly, R.P. (2011) Synthetic double-stranded RNA induces innate immune responses similar to a live viral vaccine in humans. J. Exp. Med. 208, 2357-2366.

102) Van, D.N., Roberts, C.F., Marion, J.D., Lepine, S., Harikumar, K.B., Schreiter, J., Dumur, C.I., Fang, X., Spiegel, S. and Bell, J.K. (2012) Innate immune agonist, dsRNA, induces apoptosis in ovarian cancer cells and enhances the potency of cytotoxic chemotherapeutics. FASEB J. 26, 
$3188-3198$.

103) Kanai, Y., Kawamitsu, H., Tanaka, M., Matsushima, T. and Miwa, M. (1980) A novel method for purification of poly(ADP-ribose). J. Biochem. 88, 917-920.

104) Bürkle, A. (2005) Minireview: Poly(ADP-ribose). The most elaborate metabolite of $\mathrm{NAD}^{+}$. FEBS J. 272, 4576-4589.
105) Kurkenberg, K.A., Kim, S., Tan, E.S., Maliga, Z. and Mitchison, T.J. (2015) Extracellular poly(ADP-ribose) is a pro-inflammatory signal for macrophages. Chem. Biol. 22, 446-452.

(Received Apr. 1, 2016; accepted June 22, 2016)

\section{Profile}

Yoshiyuki Kanai was born in 1942 and graduated from Jikei University, School of Medicine in 1968 to obtain the degree of medical doctor (M.D). After studying Biochemistry at the Research Institute of National Cancer Center, Tokyo, he moved to the Institute of Medical Science, University of Tokyo, where he received the degree of doctor of medical science (D.M.S) in 1974 under the leadership of Prof. Takashi Sugimura for the study on the in vivo dynamics of rat liver catalase. In 1974, Dr. Kanai was promoted to Research Associate (Assistant Professor) at the Institute of Medical Science, University of Tokyo. From 1974 to 78 in Japan, he made significant contributions to the Science of poly(ADP-ribose), such as experimental production of antibody to poly(ADP-ribose) in rabbits, finding of naturally-occurring antibody (autoantibody) to poly(ADP-ribose) in patients with systemic lupus erythematosus (SLE), and experimental induction of antibody to poly(ADP-ribose) in rabbits by heteroclitic mode through synthetic double stranded poly(A).poly(U). All of these were first-ever achievements: the first paper was published in Biochem. Biophys. Res. Commun. (BBRC) and the second and the third were in "Nature", respectively, as described in this review. From 1980 to 81, he was invited to Tufts University School of Medicine, Boston as a visiting scientist and studied there on monoclonal antibodies to nucleic acids such as poly adenosine diphosphate ribose [poly(ADP-ribose)]. In 1983, he was promoted to Associate Professor at the Institute of Medical Science, University of Tokyo.

While antibodies against double-stranded (ds)DNA, which is considered a hallmark as diagnosis of autoimmune disease SLE, couldn't be induced by immunization with even its complex with methylated bovine albumin. Dr. Kanai first identified anti-ss/dsDNA antibody-inducing factor in cultured fluid of lymphoid cell line established from autoimmune MRL/lpr/lpr mouse (Immunol. Lett. 32: 43-48, 1992), ant it was dubbed "nucleobindin (Nuc)". Molecular cloning of Nuc has revealed that it has DNA/Ca ${ }^{2+}$ binding motif (BBRC., 187: 375-380, 1992 and BBRC., 199: 1388-1393, 1994). Nuc is now recognized internationally and a large number of the papers dealing with Nuc has been published. Among which, notable one is the citation of Nuc in Oxford Dictionary of Biochemistry and Molecular Biochemistry (from the second edition) and Oxford Dictionary of Biomedicine in 2010. For this work, Dr. Kanai was awarded Japan College of Rheumatology Scientific Award in 1996.

After the retirement in 2003 from the University of Tokyo according to bylaws, Dr. Kanai has arrived at Choju Medical Institute, Fukusimura Hospital, Toyohashi, Aichi, where he have first found that patients with Alzheimer's Disease (AD) produce IgG antibody against poly(ADP-ribose) in close association to antibody against histone H1 (Kanai et al. Ann. N.Y. Acd. Sci. U.S.A., 1109: 338-344, 2007): it was really a surprise that the publication was coincided with the era of focusing of (ADP-ribosyl)ation on neurodegenerative diseases such as AD. At present, Dr. Kanai is conducting as director and governor at Fukushimura Institute of Health and Medical Services for the Aged. 